\title{
Effect of Pichia pastoris host strain on the properties of recombinant Aspergillus niger endoglucanase, EgIB
}

\section{Shazilah Kamaruddin ${ }^{1}$, Nor Muhammad Mahadi², Rosli Md Illias ${ }^{3}$, Osman Hassan ${ }^{4}$, Suhaila Sulaiman ${ }^{5}$, William Broughton $^{6}$, Izwan Bharudin', Farah Diba Abu Bakar ${ }^{1 *}$, Abdul Munir Abdul Murad1}

${ }^{1}$ School of Biosciences \& Biotechnology, Faculty of Science \& Technology, Universiti Kebangsaan Malaysia, Bangi 43600 Selangor, Malaysia.

${ }^{2}$ Institute of Systems Biology, Universiti Kebangsaan Malaysia, 43600 Bangi, Selangor, Malaysia.

${ }^{3}$ Department of Bioprocess Engineering, Faculty of Chemical and Natural Resources Engineering, Universiti Teknologi Malaysia, 81310 Skudai, Johor, Malaysia.

${ }^{4}$ School of Chemistry \& Food Technology, Faculty of Science \& Technology, Universiti Kebangsaan Malaysia, Bangi, 43600 Selangor, Malaysia.

${ }^{5}$ Felda Global Ventures Research and Development Sdn Bhd, FGV Innovation Centre (Biotechnology), Bandar Enstek, 71760 Negeri Sembilan, Malaysia.

${ }^{6}$ BAM Federal Institute for Materials Research and Testing, Unter den Eichen 87, 12205 Berlin, Germany. Email: fabyff@ukm.edu.my

\begin{abstract}
Aims: The methylotrophic yeast Pichia pastoris is widely used to express foreign proteins fused to secretion signals. As the effect of the expression host on the final protein product is unclear, we compared the properties of an endoglucanase (eg/B of Aspergillus niger) expressed in two different $P$. pastoris strains.

Methodology and results: Full-length cDNA encoding endoglucanase of $A$. niger strain ATCC10574 was isolated and expressed in $P$. pastoris X33 (the methanol utilisation plus phenotype, Mut ${ }^{+}$) and $P$. pastoris GS115 (slow methanol utilisation, Mut ${ }^{S}$ ). EgIB-GS115 showed the highest activity and stability at $60{ }^{\circ} \mathrm{C}$ while EgIB-X33 was most active at 50 ${ }^{\circ} \mathrm{C}$. EgIB-X33 was active towards other substrates such as arabinogalactan, guar gum and locust bean gum besides its specific substrate, carboxymethyl cellulose (CMC). However, EgIB-GS115 was only active on CMC. The affinity of EgIBX33 towards CMC $\left(\mathrm{K}_{\mathrm{m}}=7.5 \mathrm{mg} / \mathrm{mL}\right.$ and specific activity $\left.658 \mathrm{U} / \mathrm{mg}\right)$ was higher than that of EglB-GS115 $\left(\mathrm{K}_{\mathrm{m}}=11.57\right.$ $\mathrm{mg} / \mathrm{mL}$, specific activity $144 \mathrm{U} / \mathrm{mg}$ ).

Conclusion, significance and impact of study: Although egIB was cloned in the same expression vector ( $p P I C Z a C)$, two different characteristics of enzymes were recovered from the supernatant of the different hosts. Thus, expression of recombinant enzyme in different $P$. pastoris strains greatly affects the physical structure and biochemical properties of the enzyme.
\end{abstract}

Keywords: cellulase, endoglucanase, glycosylation, methanol utilisation phenotype, recombinant enzyme

\section{INTRODUCTION}

Pichia pastoris is widely used for high-level protein production of complex proteins in industry and research (Krainer et al., 2012). Methanol serves both as a carbon source for $P$. pastoris and as an inducer of the alcohol oxidases AOX1 and AOX2. Alcohol oxidase catalyses the conversion of methanol to formaldehyde and hydrogen peroxide (Cereghino et al., 2000). Since AOXs catalyse the first step in methanol utilisation, they can accumulate up to $35 \%$ of the total protein in cells grown on limited methanol (Sreekrishna et al., 1997) and for this reason, the strongest promoter that modulates alcohol oxidase synthesis is widely used to drive heterologous protein expression in $P$. pastoris.
The wild-type $P$. pastoris strain which is a methanol utilisation plus ( $\mathrm{Mut}^{+}$) phenotype, grows well on methanol. Loss of aox1, and thus loss of most of the cell's alcohol oxidase activity, results in strains that are phenotypically slow in methanol utilisation $\left(\mathrm{Mut}^{\varsigma}\right.$ ) (Sreekrishna et al., 1997). Muts cells therefore grows poorly on methanol containing media. The methanol-utilisation minus phenotype, Mut in which both aox-genes have been rendered inactive however, has totally lost the ability to grow on methanol.

The Pichia strain X-33 is a wild-type while GS115 strain has a mutation in the histidinol dehydrogenase gene (his4), which prevents it from synthesising histidine. Transformation of $P$. pastoris strains GS115 or X-33 with linear constructs favours single cross-over recombination 
Malays. J. Microbiol. Vol 14(6) Special Issue 2018, pp. 554-562 DOI: http://dx.doi.org/10.21161/mjm.1461814

at the aox 1 locus. Most of the resulting transformants will therefore be $\mathrm{Mut}^{+}$but aox1 sequences in the plasmid can force recombination at the $3^{\prime}$-aox 1 terminus. This causes disruption of the native aox1-gene and creates Mut $^{\mathrm{S}}$ transformants (Cereghino et al., 2000).

Expression of heterologous proteins in different $P$ pastoris strains affects expression levels and may lead to enhanced expression of targeted proteins. Since the aox 1 promoter is highly inducible, most researchers use Mut ${ }^{+}$ hosts (Macauley-Patrick et al., 2005). As an example, expression level of the peroxidase of Coprinus cinereu in a $\mathrm{Mut}^{+}$host yielded three-fold higher as compared to a Mut $^{\mathrm{S}}$ strain (Kim et al., 2009). Nevertheless, Mut ${ }^{\mathrm{S}}$ strains have other advantages (Ascacio-Martinez and BarreraSaldana, 2004; Guo et al., 2008; Krainer et al., 2012). For example, the recombinant growth hormone (rCFGH) from the canine, Canis familiaris was expressed at 40 and 15 $\mu \mathrm{g} \cdot \mathrm{mL}^{-1}$ for constructs in $\mathrm{Mut}^{\mathrm{S}}$ and $\mathrm{Mut}^{+}$hosts, respectively (Ascacio-Martinez and Barrera-Saldana, 2004). Thus, it is difficult to predict which strain/isolate will be suitable for expressing a particular protein.

To the best of our knowledge, the effect of different $P$. pastoris strains on the properties of the enzymes produced in them is not known. To address this question, we cloned the cDNA of eglB from Aspergillus niger strain ATCC10574 and produced a his-tag recombinant endoglucanase (EC 3.1.3.2) in P. pastoris strains GS115 and X33. Although the endoglucanase EgIB is derived from a mesophilic fungus, $A$. niger, it has a relatively high optimum temperature $\left(70{ }^{\circ} \mathrm{C}\right)$ and is stable for up to $3 \mathrm{~h}$ at $60{ }^{\circ} \mathrm{C}$ retaining over $90 \%$ of its original activity $\mathrm{Li}$ et al. (2012). In addition, EgIB remained active in the $\mathrm{pH} 3$ to 10 range with a tendency towards increased stability under more alkaline conditions. For all these reasons it is widely used to degrade biomass as well as in the industries such as textiles and paper and pulp industry. Thus expression of this protein in various hosts might affect their physical and biochemical properties. The aim of this study is to determine the influence of different $P$. pastoris strains on the biochemical properties of the endoglucanase, EgIB produced.

\section{MATERIALS AND METHODS}

\section{Fungi and culture conditions}

Aspergillus niger ATCC10574 was obtained from the American Type Culture Collection (ATCC) (ATCC, Manassas, VA, USA) and was cultured in Mendels medium as described by Hong et al. (2001) with $1 \%(\mathrm{w} / \mathrm{v})$ Avicel (Fluka Sigma-Aldrich, Basel, Switzerland) as inducer. The medium was autoclaved and inoculated with $10^{6}$ spores $/ \mathrm{mL}$ of $A$. niger. Fungal mycelia were harvested after $48 \mathrm{~h}$ of growth by filtration through filter paper, frozen with liquid nitrogen and stored at $80^{\circ} \mathrm{C}$ until further use.

\section{Amplification and cloning of endoglucanase cDNA}

Total RNA was extracted according to Oh et al. (2009). The RNA was used as a template for the synthesis of the first cDNA strand using a Superscript III First Strand cDNA Synthesis Kit (Invitrogen Life Technologies, Grand Island, NY, USA) and an oligo-dT primer in accordance to the manufacturer's procedure.

To obtain the full-length egIB cDNA, specific primers (Forward primer: 5'GTTGATCGAGCAGTCGTAGC3'; Reverse primer: 5'TCAGCGACAAACTGCCTAC3') were designed and synthesised according to the DNA sequence of egIB from the $A$. niger Genome Database of the Joint Genome Institute (JGI), Walnut Creek, CA, USA (http://genome.jgi psf.org/Aspni5/Aspni5.home.html). PCR was performed using a KOD Hot Start DNA Polymerase Kit (Merck KGaA, Darmstadt, Germany). The amplified cDNA was cloned into a pGEMT-Easy vector (Promega, Madison, WI, USA) and sequenced.

\section{Sequence analysis}

The full-length sequence obtained was translated into an amino acid sequence and a similarity search for the amino acid sequence against public databases was carried out using Basic Local Alignment Search Tool (BLAST) (http://www.ncbi/BLAST) (Altschul et al., 1997). The NetNGlyc 1.0 server (http://www.cbs.dtu.dk/services/NetNGlyc) and OGPET 1.0 (http://ogpet.utep.edu/OGPET) predicted the $\mathrm{N}$ glycosylation and $O$-glycosylation sites.

\section{Homology modelling}

Based on the structure of Thermoascus aurantiacus endoglucanase $1 \mathrm{H} 1 \mathrm{~N}$ (DOI:10.2210/pdb1h1n/pdb) from the Protein Data Bank (PDB), a three-dimensional homology model of EglB was generated using MODELLER9v11 (Webb et al., 2014). The sequence identity between EgIB and endoglucanase from $T$. aurantiacus was $72 \%$. The quality of the final model was checked using PROCHECK (Laskowski et al., 1993).

\section{Molecular cloning and expression in $P$. pastoris}

Construction of expression vectors was performed using eglB cDNA as the template. A fragment encoding mature EgIB (without the signal peptide) was amplified using a 5'primer containing a Cla1 site (5' ATCGATTGATGAATTGGCCTAC 3') while the 3'-primer contained a Kpn1 site (5'GTGATTCTAGATTGTGAACAGTAGGC 3') and subsequently, this amplified fragment was cloned into pPICZaC vector (Invitrogen Life Technologies, Grand Island, NY, USA). The resulting vector obtained was designated EgIB-pPICZaC.

The EgIB-pPICZaC vector was linearised and then used to transform $P$. pastoris strains X-33 and GS115 by electroporation (Electroporator 2510, Eppendorf, Hauppauge, NY, USA). Transformants obtained were 
screened for expression by identifying putative multi-copy recombinants on plates of YPD containing $1 \%(\mathrm{w} / \mathrm{v})$ yeast extract, $2 \%(\mathrm{w} / \mathrm{v})$ dextrose, $2 \%(\mathrm{w} / \mathrm{v})$ peptone and $2 \%$ $(\mathrm{w} / \mathrm{v})$ agar, with an increasing concentration of Zeocin $\AA$ $(1000 \mu \mathrm{g} / \mathrm{mL}, 1,500 \mu \mathrm{g} / \mathrm{mL}, 2000 \mu \mathrm{g} / \mathrm{mL})$. Subsequently, transformants were tested for the Mut phenotypye by growing on Minimal Methanol plates. The endoglucanase gene integration into the $P$. pastoris genome was validated by PCR amplification with the primers, 5'AOX1 (5'GACTGGTTCCAATTGACAAGC3') and 3'AOX1 (5'GCAAATGGCATTCTGACATCC 3').

Positive transformants were used to inoculate $100 \mathrm{~mL}$ of BMGY medium (buffered glycerol-complex medium, Invitrogen) in $1 \mathrm{~L}$ Erlenmeyer flasks. Only GS115 transformants were supplemented with $4 \times 10^{-3} \%(\mathrm{w} / \mathrm{v})$. The cells were cultivated with rotary shaking at $30^{\circ} \mathrm{C}$ and $250 \mathrm{rpm}$ until the $\mathrm{OD}_{600}$ reached 2-6, indicating log-phase growth. Cells to be harvested were centrifuged at $3000 \times$ $g$ for $5 \mathrm{~min}$ in room temperature. Cell pellets were resuspended in $20 \mathrm{~mL}$ BMMY medium (buffered methanolcomplex medium, Invitrogen) supplemented with $4 \times 10^{-3} \%$ $(w / v)$ histidine (for GS115 transformants) and cultivated for 3 days. A final concentration of $3 \%$ methanol $(\mathrm{v} / \mathrm{v})$ was added to the yeast cultures every $24 \mathrm{~h}$ to maintain induction. Pooled culture supernatants were concentrated using Amicon Ultra Centrifugal Filter Devices (Merck Millipore, Billerica, Massachusetts, USA). Secreted proteins were analysed using sodium dodecyl sulphatepolyacrylamide gel electrophoresis (SDS-PAGE).

\section{Purification of recombinant EgIB}

Recombinant endoglucanase $B$ proteins fused to a $6 x$ histidine tag were subjected to Ni-NTA Sepharose column purification using an AKTA Prime System (Amersham, Buckinghamshire, UK). The target protein fractions were pooled and analysed by $12 \%$ SDS-PAGE.

\section{Biochemical characterisation of EgIB}

The amount of recombinant EglB produced was measured according to the Bradford Method (Bradford, 1976). Enzymes were assayed using carboxymethyl cellulose (CMC) (Sigma Aldrich, St. Louis, MO, USA) as the substrate. The CMCase standard assay was performed by adding approximately $1 \mu \mathrm{g}$ purified EgIB to $2.5 \%(\mathrm{w} / \mathrm{v}) \mathrm{CMC}$ in $50 \mathrm{mM}$ sodium acetate buffer $\mathrm{pH} 4$ and incubated at $50{ }^{\circ} \mathrm{C}$ for $30 \mathrm{~min}$. Dinitrosalicyclic acid (DNS) assay was employed to determine the reducing sugars released (Miller, 1959). Glucose was used as a standard, and the liberation of glucose was measured at $540 \mathrm{~nm}$. Enzyme activity of one unit was defined as the amount of enzyme that produced $1 \mu$ mole of glucose in one minute using the standard assay conditions.

To determine the optimum temperature of EglB, standard assays as described previously were carried out for $30 \mathrm{~min}$ at $20,30,40,50,60,70$, and $80^{\circ} \mathrm{C}$. Stability of EglB in various temperatures was assessed by measuring the residual activity after pre-incubation of the enzyme in the absence of substrate at various temperatures between 50 to $70{ }^{\circ} \mathrm{C}$ for $30 \mathrm{~min}$. Subsequently, the residual activity of the enzyme was assayed by the standard assay method as described previously. The optimum $\mathrm{pH}$ was analysed by running the standard assay over a range of $\mathrm{pH}$ values from 3 to 8 , while $\mathrm{pH}$ stability of the enzyme was determined in $\mathrm{pH} 3-8$ at $50{ }^{\circ} \mathrm{C}$ for 30 min; residual activity was recorded as described previously. The buffers used were sodium acetate $(\mathrm{pH} 3$ to 5) and potassium phosphate ( $\mathrm{pH} 6$ to 8 ).

Michaelis-Menten constants $\left(K_{\mathrm{m}}\right)$ and maximum velocities of substrate hydrolysis $\left(V_{\max }\right)$ were calculated from Lineweaver-Burk plots. The reactions were performed by incubating $0.1 \mathrm{~mL}$ of purified EglB with 0.9 $\mathrm{mL} 50 \mathrm{mM}$ sodium citrate buffer $(\mathrm{pH} 4.0)$ with various substrates over a range of concentrations at $50{ }^{\circ} \mathrm{C}$ for 30 min. The substrates used were Avicel (Sigma Aldrich), xylan (Thomson Biotech (S) Pte. Ltd., Xiamen, Fujian, China) pNP- $\beta$-D-cellobioside, (Sigma Aldrich), pNP- $\beta$-Dglucopyranoside (Sigma Aldrich), arabinogalactan (Sigma Aldrich), LBG (Sigma Aldrich), guar gum (Rama Industries, Ahmedabad, Gujarat, India) and CMC. Enzyme activities, catalytic constants $\left(K_{\text {cat }}\right)$ and specificity constants $\left(K_{\text {cat }} / K_{m}\right)$ were calculated using standard procedures. All experiments were performed with three technical replicates and two biological replicates.

\section{RESULTS}

\section{Isolation and sequence analysis of $A$. niger eglB cDNA}

The egIB cDNA comprised $996 \mathrm{bp}$, encoding a polypeptide of 331 amino acid residues and had an estimated molecular mass of $34.8 \mathrm{kDa}$. BLAST analyses showed that the EglB amino acid sequence was $100 \%$ identical to that of EgIB of $A$. niger strain BCRC31494 (Accession number: ACT68011.1) (Li et al., 2012).

EgIB and the endoglucanase of Thermoascus aurantiacus share $72 \%$ identity and for this reason the $T$. aurantiacus endoglucanase $1 \mathrm{H} 1 \mathrm{~N}$ (DOI:10.2210/pdb1h1n/pdb) was used to build a model of EglB (Figure 1) (Van-Petegem et al., 2002). This model was verified by PROCHECK and Ramachandran Plot analyses which showed that $91 \%$ of the residues were in the most favoured regions. Three predicted $\mathrm{N}$ glycosylation sites were found on the protein (Figure 1), two (N100 and N211) at the surface while N38 was located inside the barrel, next to the two catalytic residues. Glycosyl hydrolase family 5, possesses two invariant glutamic acid residues that correspond to a nucleophile and proton donor (Wang et al., 1993) both of which were present in EgIB (Figure 1). The Glu-160 residue is the potential catalytic proton donor, while Glu226 is the potential nucleophile in the displacement reaction. Several other important residues surrounded the N38 sites including Trp-299, a residue implicated in substrate-binding and His-120 which contacts the sugar residue in subsite-1 (Domínguez et al., 1996; VanPetegem et al., 2002). A further two residues (His-224 
Malays. J. Microbiol. Vol 14(6) Special Issue 2018, pp. 554-562 DOI: http://dx.doi.org/10.21161/mjm.1461814

and Tyr-226) near N38 that interact with the nucleophile were also present.

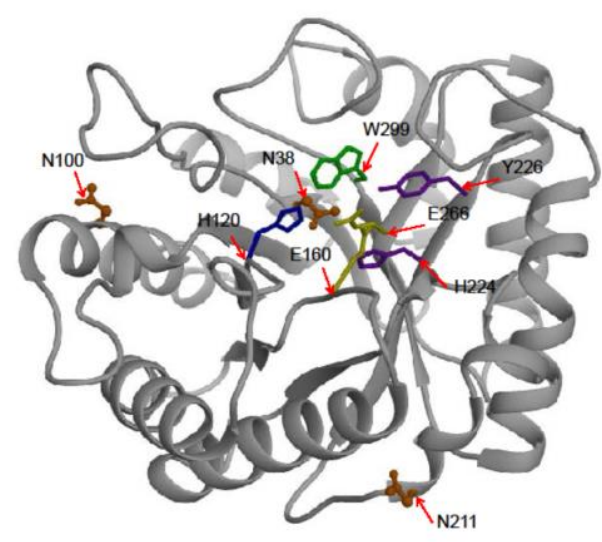

Figure 1: Homology model of EglB (generated using the MODELLER 9.11 programme) showing all secondary structure elements with arrows representing important amino acids. The two catalytic residues labelled E160 and E266 and three $\mathrm{N}$-glycosylation sites predicted are labelled as N38, N100 and N211. Aromatic residues possibly involved in the binding of substrates are also shown and labelled as H224, Y226, H120 and W299.

\section{Expression and purification of EglB}

Partially purified samples containing EglB of both $P$. pastoris strains X-33 and GS115 revealed a recombinant protein of $\sim 46 \mathrm{kDa}$ for EglB-X33 and $\sim 58 \mathrm{kDa}$ for EglBGS115 (Figure 2). These values are slightly higher than that predicted for EglB with a histidine tag $(38 \mathrm{kDa})$. Most likely this was due to the $\mathrm{N}$-glycosylation, something that was predicted by in silico analyses of the EgIB amino acid sequence. No O-glycosylation sites were found.

\section{Biochemical properties of EglB}

Purified EgIB-X33 and EgIB-GS115 exhibited maximal activity on $\mathrm{CMC}$ at $\mathrm{pH} 4.0$ (Figure 3a). Activity declined rapidly to $40 \%$ in alkaline $\mathrm{pH}$ at $\mathrm{pH} 8.0$, a characteristic of most fungal cellulases that often limits their application under neutral or alkaline conditions (Wang et al., 2005). Nevertheless, both endoglucanases were very stable over a wide range of $\mathrm{pHs}$; stability even increased towards alkaline $\mathrm{pH}$ (Figure $3 \mathrm{~b}$ ). Stability was marked between $\mathrm{pH}$ 5.0 and 8.0. Both endoglucanases retained more than $80 \%$ of the maximum activity at $\mathrm{pH} 8.0$ after incubation at $50{ }^{\circ} \mathrm{C}$ for $30 \mathrm{~min}$ and lost almost $80 \%$ of its maximal activity at $\mathrm{pH} 4.0$ under the same conditions.

The optimum temperature of EgIB-X33 for hydrolysis of $\mathrm{CMC}$ was $50{ }^{\circ} \mathrm{C}$ (at pH 4.0) (Figure 3c) with over $50 \%$ of maximal activity at $70{ }^{\circ} \mathrm{C}$. EglB-X33 was relatively stable up to $60^{\circ} \mathrm{C}$ (Figure $3 \mathrm{~d}$ ) retaining $80 \%$ of its original activity but was completely inactive at $70{ }^{\circ} \mathrm{C}$. In contrast, the optimum temperature of EgIB-GS115 for CMC hydrolysis was $60{ }^{\circ} \mathrm{C}(\mathrm{pH} 4.0)$ (Figure 3b) and the enzyme had a broader optimum temperature range, with over $50 \%$ of maximal activity at $80^{\circ} \mathrm{C}$. EglB-GS115 was $100 \%$ stable up to $60{ }^{\circ} \mathrm{C}$ (Figure $3 \mathrm{~b}$ ) but only retained $20 \%$ activity at $70^{\circ} \mathrm{C}$.

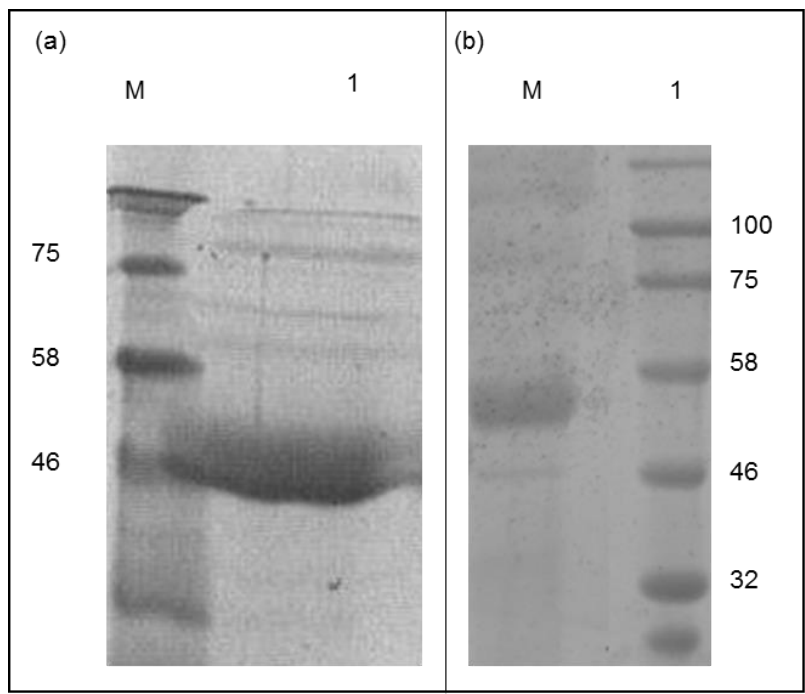

Figure 2: SDS-PAGE of recombinant EgIB endoglucanase on $12 \%$ polyacrylamide gels. a) Lane 1 : $M$, Protein Marker Broad Range (NEB, Ipswich, Massachusetts, USA), 2: Purified protein of $P$. pastoris $\mathrm{X}$ 33/EgIB_pPICZaC. b) Lane 1: Purified protein of $P$. pastoris GS115/EglB_pPICZaC, 2: M, Protein Marker Broad Range (NEB, Ipswich, Massachusetts, USA).

\section{Kinetic parameters of recombinant EgIB}

EgIB-X33 had significant activity on four soluble substrates: arabinogalactan, CMC, guar gum and LBG but were highest on CMC (specific activity - $658 \mathrm{U} / \mathrm{mg}$ ) followed by arabinogalactan, guar gum and LBG (344 $\mathrm{U} / \mathrm{mg}, 46 \mathrm{U} / \mathrm{mg}$ and $39 \mathrm{U} / \mathrm{mg}$ respectively) (Table 1 ). However, the enzyme was inactive on insoluble or synthetic substrates such as Avicel ${ }^{\mathrm{TM}}$, pNP- $\beta$-Dcellobioside, pNP- $\beta$-D-glucopyranoside and xylan. Interestingly, EgIB-GS115 was specific to CMC (specific activity $144 \mathrm{U} / \mathrm{mg}$ ) being inactive on all other soluble and insoluble substrates.

Specificity of enzymes (= the specificity constant) is often expressed in terms of the $K_{\text {cat }} / K_{m}$ (catalytic efficiency), a useful index for comparing the relative rates of activity on alternative, competing substrates (Pham et al., 2011). EgIB-X33 had broad substrate specificity and was able to hydrolyse both $\beta$ - $(1,4)$-linked glucose and $\beta$ $(1,4)$-linked mannose residues, as well as $\beta$ - $(1,3)$-linked galactan. Yet the $K_{\text {cat }} / K_{m}$ of EglB-X33 was highest towards arabinogalactan (136 $\left.\mathrm{s}^{-1} . \mathrm{mg} \mathrm{mL}^{-1}\right)$ rather than CMC (56 s $\mathrm{s}^{-1} \cdot \mathrm{mg} \mathrm{mL}^{-1}$ ) which gave the highest specific activity. EgIB-GS115 that was only able to hydrolyse $\mathrm{CMC}$, had a $K_{\text {cat }} / K_{\mathrm{m}}$ of $11.3 \mathrm{~s}^{-1} . \mathrm{mg} \mathrm{mL}^{-1}$. 
Malays. J. Microbiol. Vol 14(6) Special Issue 2018, pp. 554-562

DOI: http://dx.doi.org/10.21161/mjm.1461814

Table 1: Kinetic parameters of EgIB.

\begin{tabular}{|c|c|c|c|c|c|c|}
\hline Enzymes & $\begin{array}{l}\text { Substrate/Kinetics } \\
\text { parameters }\end{array}$ & $\begin{array}{l}V_{\max } \\
(\mu \mathrm{mole} / \min )\end{array}$ & $\begin{array}{l}K_{\mathrm{m}} \\
(\mathrm{mg} / \mathrm{mL})\end{array}$ & $K_{\text {cat }}$ & $K_{\text {cat }} / K_{\mathrm{m}}$ & $\begin{array}{l}\text { Specific activity } \\
(\mathrm{U} / \mathrm{mg})\end{array}$ \\
\hline \multirow{8}{*}{ EglB-X33 } & $\mathrm{CMC}$ & 0.0461 & 7.50 & 417.38 & 55.65 & 658 \\
\hline & Arabinogalactan & 0.0241 & 1.60 & 218.65 & 136.66 & 344 \\
\hline & Locust bean gum & 0.0027 & 0.30 & 24.72 & 82.39 & 38.9 \\
\hline & Guar gum & 0.0032 & 0.49 & 29.13 & 59.46 & 45.9 \\
\hline & Xylan & n.d & & & & \\
\hline & Avicel & n.d & & & & \\
\hline & pNP- $\beta$-D-cellobioside & n.d & & & & \\
\hline & pNP- $\beta$-D-glucopyranoside & n.d & & & & \\
\hline \multirow{8}{*}{ EgIB-GS115 } & $\mathrm{CMC}$ & 1.44 & 11.57 & 130 & 11.3 & 144 \\
\hline & Arabinogalactan & n.d & & & & \\
\hline & Locust bean gum & n.d & & & & \\
\hline & Guar gum & n.d & & & & \\
\hline & Xylan & n.d & & & & \\
\hline & Avicel & n.d & & & & \\
\hline & pNP- $\beta$-D-cellobioside & n.d & & & & \\
\hline & pNP- $\beta$-D-glucopyranoside & n.d & & & & \\
\hline
\end{tabular}

n.d.: not detectable

Table 2: Biochemical properties of EgIB-X33 compared to other EgIB in various hosts.

\begin{tabular}{|c|c|c|c|c|}
\hline Enzymes/properties & EglB-Wild Type & EglB_GS115_Li & EglB-GS115 & EglB-X33 \\
\hline Origin & A. niger ATCC 10577 & A. niger BCRC31494 & $\begin{array}{l}\text { A. niger } \\
\text { ATCC10574 }\end{array}$ & $\begin{array}{l}\text { A. niger } \\
\text { ATCC10574 }\end{array}$ \\
\hline $\begin{array}{l}\text { Protein mass (without } \\
\text { deglycosylation) kDA }\end{array}$ & 43 & 51 & $\sim 58$ & $\sim 46$ \\
\hline Expression host & Native & $\begin{array}{l}\text { P. pastoris GS115 } \\
\text { (MutS) }\end{array}$ & $\begin{array}{l}\text { P. pastoris GS115 } \\
\text { (MutS) }\end{array}$ & $\begin{array}{l}\text { P. pastoris X33 } \\
\text { (Mut+) }\end{array}$ \\
\hline Expression vector & - & pPICZaC & pPICZaC & pPICZaC \\
\hline Optimum temperature & $60^{\circ} \mathrm{C}$ & $70^{\circ} \mathrm{C}$ & $60^{\circ} \mathrm{C}$ & $50^{\circ} \mathrm{C}$ \\
\hline $\begin{array}{l}\text { Temperature stability } \\
\text { (relative activity }>70 \% \text { ) }\end{array}$ & $20-50^{\circ} \mathrm{C}$ & $30-60^{\circ} \mathrm{C}$ & $50-60^{\circ} \mathrm{C}$ & $50-60^{\circ} \mathrm{C}$ \\
\hline$K_{\mathrm{m}}$ towards $\mathrm{CMC}$ & $4.7 \mathrm{mg} / \mathrm{mL}$ & $135 \mathrm{mg} / \mathrm{mL}$ & $11.57 \mathrm{mg} / \mathrm{mL}$ & $7.5 \mathrm{mg} / \mathrm{mL}$ \\
\hline Specific activity $\left(\mathrm{U} \cdot \mathrm{mg}^{-1}\right)$ & 24.6 & 0.76 & 144 & 658 \\
\hline Reference & (Vidmar et al., 1984) & (Li et al., 2012) & This study & This study \\
\hline
\end{tabular}

$1 \mathrm{U}$ : The amount of enzyme releasing $1 \mu$ mole of glucose per minute under standard condition 
a)

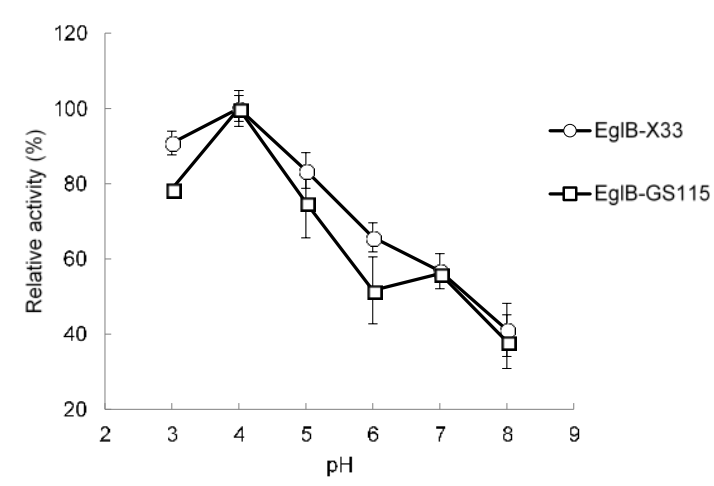

b)

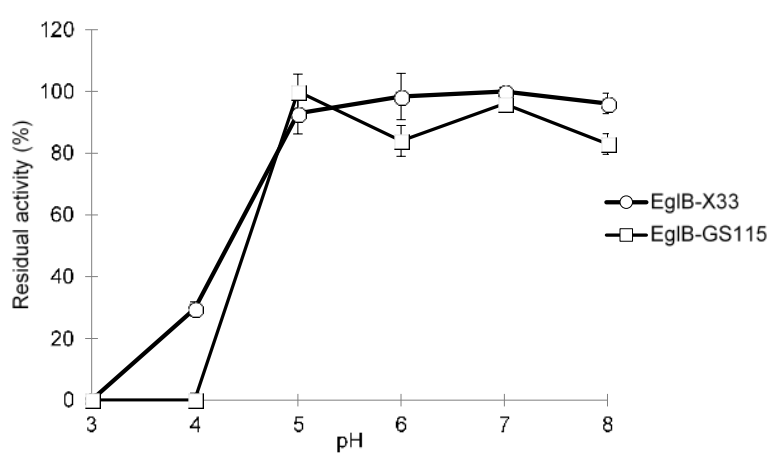

c)

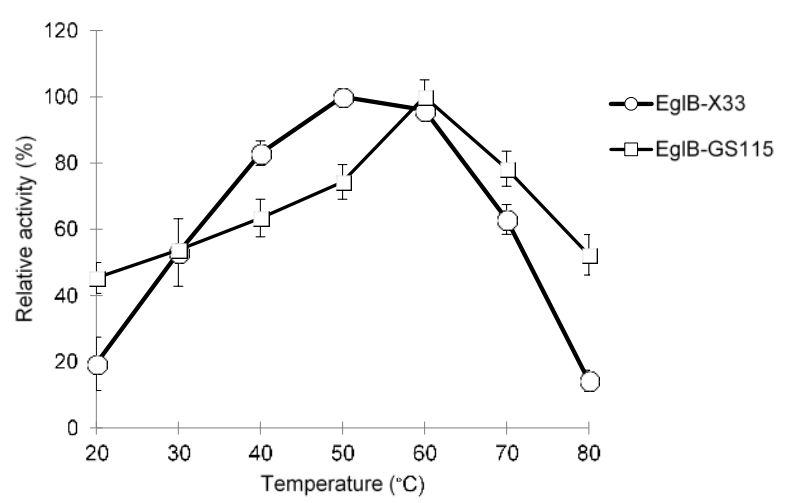

d)

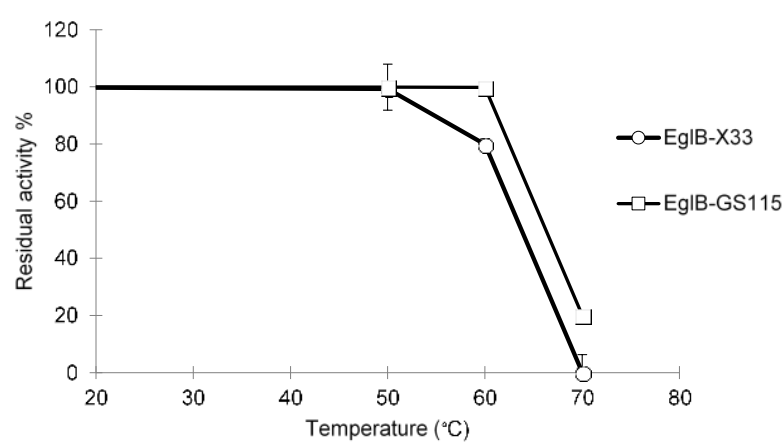

Figure 3: Characterisation of EgIB in terms of: (a) optimum pH for maximal activity. The highest activities taken as $100 \%$ relative activity that were equivalent to $658 \mathrm{U} / \mathrm{mg}$ for EglB-X33 and $144 \mathrm{U} / \mathrm{mg}$ for EglB-GS115 respectively; b) stability of EglB at various $\mathrm{pH}$ values; (c) optimum temperature for maximal activity. The highest activities taken as $100 \%$ relative activity that were equivalent to $658 \mathrm{U} / \mathrm{mg}$ for EglB-X33 and $144 \mathrm{U} / \mathrm{mg}^{-1}$ for EglB-GS115 respectively, and; (d) stability at various temperatures.

\section{Comparison of EglB produced in $P$. pastoris strain X33 and strain GS115}

We compared the biochemical properties of recombinant EgIB (EgIB-X33; Mut $^{+}$and EgIB-GS115; Mut $^{\mathrm{S}}$ ) with that produced naturally in $A$. niger (EglB-wild type) along with EgIB expressed in $P$. pastoris GS115; Mut' by (Li et al., 2012) (EgIB_GS115_Li) (Table 2). Variation was abundant including protein size that differed slightly between all endoglucanases. EgIB-GS115 Li was the largest protein (58 kDa) while EgIB-X33, EgIB-GS115 and EglB-wild type were 46,51 and $43 \mathrm{kDa}$ respectively. The optimum temperature of EgIB-X33 was lower than that of EglB-wild type and EgIB-GS115 in this study with an optimum of $50{ }^{\circ} \mathrm{C}$. Optimum temperatures of EglB-GS115 and EgIB-wild type were both $60^{\circ} \mathrm{C}$ while EgIB_GS115_Li was $70^{\circ} \mathrm{C}$. $K_{\mathrm{m}}$ values towards $\mathrm{CMC}$ varied even more. EglB-X33 had a $K_{\mathrm{m}}$ of $7.5 \mathrm{mg} / \mathrm{mL}$ similar to that EglB-wild type $(4.7 \mathrm{mg} / \mathrm{mL})$ (Vidmar et al., 1984). Our EgIB-GS115, along with the one reported by $\mathrm{Li}$ et al. (2012) (EgIB GS115 Li) had a very low affinities towards CMC ( $K_{\mathrm{m}}$ values of 11.6 and $135 \mathrm{mg} / \mathrm{mL}$ respectively). There are also variations seen in specific activities. EglB-X33 had the highest specific activity $(658 \mathrm{U} / \mathrm{mg})$ while EgIB-
GS115 was $144 \mathrm{U} / \mathrm{mg}$, EglB-wild type $25 \mathrm{U} / \mathrm{mg}$ and EgIB_GS115_Li $0.8 \mathrm{U} / \mathrm{mg}$ (Li et al., 2012). These differences clearly show that expression of the same protein in different strains and phenotype has large effects on the biochemical properties of the enzyme.

\section{DISCUSSION}

Glycosyl hydrolase family 5 includes cellulases, mannanases and xylanases. Biely and Tenkanen (1999) showed that all $T$. reesei endoglucanases are able to hydrolyse glucomannan. Vlasenko et al. (2009) examined family 5 endoglucanases phylogenetically and suggested that endoglucanase and mannanase activities might originate from an ancestral protein that used mannan as a substrate.

We posed the question - is the amino acid sequence of an endoglucanase the sole determinant of substrate specificity? In this study, we report the characterization of EglB, an endoglucanase from $A$. niger expressed in $P$. pastoris strain X33 (EgIB-X33) and strain GS115 (EglBGS115). This enzyme was previously expressed and characterised in $P$. pastoris strain GS115 by Li et al. (2012) (EgIB_GS115_Li). By using identical coding 
sequences but expressing the constructs in various $P$. pastoris cytoplasmic backgrounds, we expected only minimal differences between the recombinant enzymes. However, detailed study of the recombinant enzymes revealed substantial differences in activity, substrate affinity, optimum temperature and stability. EgIB-X33 can degrade locust bean gum, a hemicellulose substrate besides CMC which is a normal substrate for endoglucanases while EgIB-GS115 in this study was restricted to hydrolyse only CMC. Since both EgIB-X33 and EgIB-GS115 share the same gene sequence, the differences in activity, substrate affinity, optimum temperature and stability might be due to the posttranslational modifications in the host. Thus, it can also be postulated that the expression in different Mut phenotype strains is the main factor that contributes to the differences between these two enzymes. Furthermore, the methanol utilisation phenotype (Mut) affected growth rate probably led to different glycosylation patterns. Muts strains grew more slowly, suggesting that posttranslational processes may also take longer while Mut $^{+}$ strains are characterised by a higher growth rate than Mut ${ }^{\mathrm{S}}$. Computer predictions suggested that EgIB in this study has three $\mathrm{N}$-glycosylation sites and when produced in strain GS115 (slow methanol utilisation) resulted in a molecular mass of $\sim 58 \mathrm{kDa}$ but expression in strain X-33 gave a molecular mass of only $\sim 46 \mathrm{kDa}$. We suggest that the length of the oligosaccharide chain at the $\mathrm{N}$ glycosylation site varied because glycosylation is not a template-driven/proof-reading process. Thus, factors such as the expression host, development and differentiation of the host-cells that are all dependent on culture conditions including media composition (Bretthauer et al., 1999; Guo et al., 2008) modulate the molecular properties of the expressed protein. Different growth rates also might lead to different glycosylation patterns, thereby producing different glycoproteins. The occurrence of glycosylation in some proteins has been suggested to has a little effect on its activity (Han et al., 1999; Hamilton et al., 2007), but glycosylation on some proteins showed tremendous effect on its function such as changing its role from inhibitor to a substrate (Mochizuki et al., 2001). Thus the differences in glycosylation patterns in EgIB-X33 and EgIB-GS115 may have resulted in different lengths and moieties of carbohydrate chains that subsequently affect the affinity of both recombinant proteins towards $\mathrm{CMC}$ as well as their activity. EgIB-X33 demonstrates higher activity towards CMC (658 U/mg) compared to EgIB-GS115 (144 $\mathrm{U} / \mathrm{mg}$ ). EgIB-X33 also has a stronger affinity towards CMC as compared to EgIB-GS115 in which the $K_{\mathrm{m}}$ value is $7.5 \mathrm{mgmL}^{-1}$ and $11.57 \mathrm{mg} / \mathrm{mL}$ respectively. It can be postulated that glycosylation in the slower growing Mut ${ }^{\mathrm{s}}$ strain is more complete since it takes a longer time to fulfil the post-translational modification process. Therefore, the Mut $^{\mathrm{s}}$ strain might produce a longer carbohydrate chain that makes the EglB enzyme more stable at a higher temperature as compared to when the enzyme was expressed in the $\mathrm{Mut}^{+}$strain. However, more carbohydrate chains produced near the loop of binding site and as well as the active site might affect its affinity and activity towards CMC. The EgIB produced in the Mut ${ }^{+}$ strain (EgIB-X33) might be less glycosylated at this particular site, therefore the enzyme becomes less stable at a higher temperature but has strong affinity and activity towards CMC. As shown in Figure 1, a predicted glycosylation site was identified at the asparagine residue (N38). This position is near the substrate-binding site which is between $\beta 6$ and $\alpha 6$ (Van-Petegem et al., 2002). This glycosylation site is also near two catalytic residues at the active site of this protein. Therefore, the addition of a carbohydrate chain at this position might interrupt the binding of the substrate with this enzyme and also affect its catalytic activity.

EglB-X33 has a lower optimum temperature and stability compared to the EgIB-GS115. The optimal temperature of EgIB-X33 for CMC hydrolysis was achieved at $50{ }^{\circ} \mathrm{C}$ in sodium acetate buffer $\mathrm{pH} 4.0$ (Figure $3 b)$. The enzyme shows a broader optimum temperature range, having $96 \%$ of its maximal optimum activity at 60 ${ }^{\circ} \mathrm{C}$ and $63 \%$ at $70{ }^{\circ} \mathrm{C}$. A thermostability assay of EgIB-X33 revealed that it is relatively stable up to $60{ }^{\circ} \mathrm{C}$ (Figure $3 \mathrm{~b}$ ). EgIB-GS115 has maximal activity at $60^{\circ} \mathrm{C}$ and possesses high thermotolerance having $78 \%$ of its maximal activity at $70{ }^{\circ} \mathrm{C}$ and more than $50 \%$ activity at $80^{\circ} \mathrm{C}$. In terms of thermostability, EgIB-X33 completely lost its activity after 30 min incubation at $70{ }^{\circ} \mathrm{C}$, while EgIB-GS115 retained at least $20 \%$ of its maximal activity after 30 min incubation at $70{ }^{\circ} \mathrm{C}$.

In general, proteins that have been glycosylated might display differences in stability even though there are no major changes in their structure. It has been suggested that a single carbohydrate is sufficient to stabilise the region surrounding the glycosylation site (Imperiali and O'connor, 1999) and N-glycosylation has been given the most attention since it often contribute to protein function (Hamilton et al., 2007). EglB was predicted to have three $\mathrm{N}$-glycosylation sites; where two of them are positioned at the surface of the enzyme. Some amino acid residues at the surface of the enzyme have been proven to play an important role on the stability of the enzyme (Wang et al., 2005). The rate of post-translational modification process might lead to differences in the length of the carbohydrate chain or carbohydrate moiety that eventually will affect the optimum temperature and stability of the protein. Furthermore, the thermostability in endoglucanases is also fold specific (Yennamalli et al., 2011). Since glycosylation can affect the secondary structure of a protein, it might have an ability to direct protein folding, destabilise the unfolded state or enhance the reversibility of the unfolding process by increasing the protein solubility or discouraging the formation of aggregates. Therefore, the modification of secondary structures might also enhance the overall stability of the protein as well as enable it to perform a new function at the affected site (Imperiali and O'Connor, 1999).

\section{CONCLUSION}

In this study, we demonstrate the effect of different $P$. pastoris strains and phenotype towards the biochemical 
Malays. J. Microbiol. Vol 14(6) Special Issue 2018, pp. 554-562 DOI: http://dx.doi.org/10.21161/mjm.1461814

properties of EgIB. In future experiments, we will carry out functional and mutational analysis particularly at the glycosylation site to examine the role of different cytoplasmic backgrounds (especially the Mut-phenotype) on glycosylation and other post-translational modifications on the activity and conformation of EglB.

\section{ACKNOWLEDGEMENTS}

This work was supported by the National Biotechnology Directorate, MOSTI, Malaysia through research grant 07 05-16-MGI-GMB12.

\section{REFERENCES}

Altschul, S. F., Madden, T. L., Schaffer, A. A., Zhang, J., Zhang, Z., Miller, W. and Lipman, D. J. (1997). Gapped BLAST and PSI-BLAST: A new generation of protein database search programs. Nucleic Acids Research 25, 3389-3402.

Ascacio-Martinez, J. and Barrera-Saldana, H. (2004). Production and secretion of biologically active recombinant canine growth hormone by Pichia pastoris. Gene 340, 261-266.

Biely, P. and Tenkanen, M. (1999). Enzymology of hemicellulose degradation. In: Trichoderma and Gliocladium. Enzymes, Biological Control and Commercial Applications. Kubicek, C. P. and Harman, G. E. (eds.). Taylor and Francis, London. pp. 25-47.

Bradford, M. M. (1976). A rapid and sensitive method for the quantitation of microgram quantities of protein utilizing the principle of protein-dye binding. Analytical Biochemistry 72, 248-254.

Bretthauer, R. K. and Castellino, F. J. (1999). Glycosylation of Pichia pastoris-derived proteins. Biotechnology Applied Biochemistry 30(Pt 3), 193200.

Cereghino, J. L. and Cregg, J. M. (2000). Heterologous protein expression in the methylotrophic yeast Pichia pastoris. FEMS Microbiology Review 24, 45-66.

Domínguez, R., Souchon, H., Lascombe, M. B. and Alzari P, M. (1996). The crystal structure of a family 5 endoglucanase mutant in complexed and uncomplexed forms reveals an induced fit activation mechanism. Journal of Molecular Biology 257, 10421051.

Guo, M., Hang, H., Zhu, T., Zhuang, Y., Chu, J. and Zhang, S. (2008). Effect of glycosylation on biochemical characterization of recombinant phytase expressed in Pichia pastoris. Enzyme and Microbial Technology 42, 340-345.

Hamilton, S. R. and Gerngross, T. U. (2007). Glycosylation engineering in yeast: The advent of fully humanized yeast. Current Opinion in Chemical Biology 18, 387-392.

Han, Y and Lei, X. G. (1999). Role of glycosylation in the functional expression of an Aspergillus niger phytase (phyA) in Pichia pastoris. Archives of Biochemistry and Biophysics 364, 83-90.
Hong, J., Tamaki, H., Akiba, S., Yamamoto, K. and Kumagai, H. (2001). Cloning of a gene encoding a highly stable endo- $\beta$-1,4-glucanase from Aspergillus niger and its expression in yeast. Journal of Bioscience and Bioengineering 92, 434-441.

Imperiali, B. and O'Connor, S. E. (1999). Effect of Nlinked glycosylation on glycopeptide and glycoprotein structure. Current Opinion in Chemical Biology 3, 643649.

Kim, S. J., Lee, J. A., Kim, Y. H. and Song, B. K. (2009). Optimization of the functional expression of Coprinus cinereus peroxidase in Pichia pastoris by varying the host and promoter. Journal of Microbiology and Biotechnology 19, 966-971.

Krainer, F., Dietzsch, C., Hajek, T., Herwig, C., Spadiut, O. and Glieder, A. (2012). Recombinant protein expression in Pichia pastoris strains with an engineered methanol utilization pathway. Microbial Cell Factories 11(1), 22.

Laskowski, R. A., MacArthur, M. W., Moss, D. S. and Thornton, J. M. (1993). PROCHECK: A program to check the stereochemical quality of protein structures. Journal of Applied Crystallography 26, 283-291.

Li, C. H., Wang, H. R. and Yan, T. R. (2012). Cloning, purification, and characterization of a heat-and alkaline-stable Endoglucanase B from Aspergillus niger BCRC31494. Molecules 17, 9774-9789.

Macauley-Patrick, S., Fazenda, M. L., McNeil, B. and Harvey, L. M. (2005). Heterologous protein production using the Pichia pastoris expression system. Yeast 22, 249-270.

Mochizuki, S., Hamato, N., Hirose, M., Miyano, K., Otani, W., Kameyama, S., Kuwae, S., Tokuyama, T and Ohi, H. (2001). Expression and characterization of recombinant human antithrombin III in Pichia pastoris. Protein Expression and Purification 23(1), 55-65.

Miller, G. L. (1959). Use of dinitrosalicylic acid reagent for determination of reducing sugar. Analytical Chemistry 31, 426-428.

Oh, S. S. L., Abu Bakar, F. D., Adnan, A. M., Mahadi, N. M., Hassan, O. and Abdul Murad, M. A. (2009). Isolation and characterization of glyceraldehydes-3phosphate dehydrogenase gene of Trichoderma virens UKM1. Biotechnology 8, 194-203.

Pham, T. H., Quyen, D. T., Nghiem, N. M. and Vu, T. D. (2011). Cloning, expression, purification, and properties of an endoglucanase gene (glycosyl hydrolase family 12) from Aspergillus niger VTCCF021 in Pichia pastoris. Journal of Microbiology and Biotechnology 21(10), 1012-1020.

Sreekrishna, K., Brankamp, R. G., Kropp, K. E., Blankenship, D. T., Tsay, J. T., Smith, P. L., Wierschke, J. D., Subramaniam, A. and Birkenberger, L. A. (1997). Strategies for optimal synthesis and secretion of heterologous proteins in the methylotrophic yeast Pichia pastoris. Gene 190, 55-62.

Van-Petegem, F., Vandenberghe, I., Bhat, M. K. and Van-Beeumen, J. (2002). Atomic resolution structure 
Malays. J. Microbiol. Vol 14(6) Special Issue 2018, pp. 554-562 DOI: http://dx.doi.org/10.21161/mjm.1461814

of the major endoglucanase from Thermoascus aurantiacus. Biochemical and Biophysical Research Communications 296, 161-166.

Vidmar, S., Turk, V. and Kregar, I. (1984). Cellulolytic complex of Aspergillus niger under conditions for citric acid production. Isolation and characterization of two $\beta$-(1,4)-glucan hydrolases. Applied Microbiology and Biotechnology 20, 326-330.

Vlasenko, E., Schülein, M., Cherry, J. and $\mathrm{Xu}, \mathrm{F}$. (2009). Substrate specificity of family $5,6,7,9,12$, and 45 endoglucanases. Bioresource Technology 101, 2405-2411.

Wang, Q., Tull, D., Meinke, A., Gilkes, N. R., Warren, R. A., Aebersold, R. and Withers, S. G. (1993). Glu280 is the nucleophile in the active site of Clostridium thermocellum CelC, a family A endo-beta-1,4glucanase. Journal of Biological Chemistry 268, 14096-14102.

Wang, T., Liu, X., Yu, Q., Zhang, X., Qu, Y., Gao, P. and Wang, T. (2005). Directed evolution for engineering $\mathrm{pH}$ profile of endoglucanase III from Trichoderma reesei. Biomolecular Engineering 22, 89-94.

Webb, B. and Sali, A. (2014). Protein structure modeling with MODELLER. In: Protein Structure Prediction. Springer, New York. pp. 1-15.

Yennamalli, R., Rader, A., Wolt, J. and Sen, T. (2011). Thermostability in endoglucanases is fold-specific. BMC Structural Biology 11, 10. 